\title{
Karakteristik Fisik, Kimia dan Organoleptik Cookies Bayam Hijau (Amaranthus tricolor) dengan Penambahan Tomat (Solanum lycopersicum) sebagai Upaya Pemenuhan Defisiensi Zat Besi pada Anak-Anak \\ Characteristic of Physical, Chemical and Organoleptic Properties of Spinach Cookies (Amaranthus Tricolor) With the Addition of Tomato (Solanum Lycopersicum) As an Effort to Prevent Iron Deficiency on Children
}

\author{
Bara Yudhistira * Tri Ratna Sari dan Dian Rachmawanti Affandi \\ Program Studi Ilmu Teknologi Pangan Universitas Sebelas Maret \\ Jl. Ir. Sutami 36A Surakarta 57126 Jawa Tengah Indonesia
}

\section{Riwayat Naskah:}

Diterima 07, 2019 Direvisi 09, 2019 Disetujui 10, 2019

\begin{abstract}
ABSTRAK: Penelitian ini bertujuan untuk mengetahui pengaruh penambahan tomat terhadap sifat fisik, kimia dan organoleptik cookies, formula terbaik cookies serta mengetahui golongan zat besi cookies menurut Acuan Label Gizi (ALG). Sifat fisik yang diteliti yaitu tekstur (kekerasan). Sifat kimia meliputi kadar air, kadar abu, kadar protein, kadar lemak, kadar karbohidrat, kadar serat kasar, kadar zat besi dan kadar vitamin C dan sifat organoleptiknya meliputi warna, aroma, rasa, tekstur dan keseluruhan. Rancangan percobaan dalam penelitian ini menggunakan Rancangan Acak Lengkap (RAL) dengan satu faktor yaitu variasi penambahan tomat dengan dua kali ulangan sampel dan dua kali ulangan analisis. Hasil penelitian menunjukkan bahwa cookies bayam hijau dengan penambahan tomat 35\% masih diterima oleh panelis. Semakin tinggi penambahan tomat dapat meningkatkan kekerasan, kadar air, kadar serat kasar, kadar zat besi serta kadar vitamin C dari cookies. Penambahan tomat $25 \%$ merupakan formula terbaik cookies dengan kandungan zat besi 40,76 ppm yang termasuk ke dalam sumber zat besi.
\end{abstract}

Kata Kunci: zat besi, cookies, bayam hijau, tomat, formula

ABSTRACT: This study aimed to determine the characteristic of physical, chemical and organoleptic cookies, determine the best cookies formula and determine the Fe class on cookies based on Acuan Label Gizi (ALG). The physical properties examined were the texture (hardness). The chemical properties contained water content, protein content, fat content, carbohydrate content, crude fiber content, iron content, and vitamin C content. While organoleptic properties were included the parameters of color, flavor, taste, texture and overall. The experimental design in this research using a Completely Randomized Design with one factor that was the variation of tomato addition made with two replications sample and two replications analysis. The results showed that the spinach cookies with of addition tomato $35 \%$ acceptable by the panelists. Higher of addition tomato that used can increase of hardness (Fmax), water content, crude fiber content, iron content, and vitamin C content. Cookies with $25 \%$ tomato is the best formula which contains iron 40,76 ppm and considered as the iron source.

Keywords: iron, cookies, spinach, tomato, formula

Kontributor utama

Email : barayudhistira@staff.uns.ac.id 
Citation: Yudhistira, B., Sari, T.R., dan Affandi, D.R. (2019). Karakteristik Fisik, Kimia dan Organoleptik Cookies Bayam Hijau (Amaranthus tricolor) dengan Penambahan Tomat (Solanum lycopersicum) sebagai Upaya Pemenuhan Defisiensi Zat Besi pada Anak-Anak. Warta IHP, 36(2),83-95

Halaman | 84

\section{Pendahuluan}

Anemia defisiensi zat besi adalah anemia yang terjadi akibat kekurangan zat besi dalam darah, artinya konsentrasi hemoglobin dalam tubuh berkurang karena terganggunya pembentukan selsel darah merah akibat kurangnya kadar besi dalam darah. Kejadian anemia defisiensi zat besi di Indonesia masih merupakan masalah kesehatan masyarakat. Dampak anemia selama masa kanakkanak dan remaja memiliki implikasi serius untuk berbagai hasil yaitu gangguan pertumbuhan fisik dan perkembangan mental, melemahnya perilaku dan perkembangan kognitif, berkurangnya kebugaran fisik dan prestasi kerja, termasuk konsentrasi dalam belajar dan pekerjaan. Beberapa faktor yang berpengaruh terhadap defisiensi zat besi adalah faktor nutrisi, yaitu akibat kurangnya jumlah besi total dalam makanan (asupan yaang kurang) atau kualitas besi (bioavailabilitas) yang rendah dan penyerapan zat besi dalam tubuh yang masih rendah (Passi, 2001).

Strategi efektif yang dapat digunakan untuk mencegah dan mengendalikan anemia gizi pada anak-anak adalah salah satunya dengan melakukan intervensi berbasis makanan (perbaikan diet, fortifikasi makanan dengan zat besi) dan intervensi non-pangan (suplementasi besi dan penanggulangan penyakit cacingan). Fortifikasi pangan adalah penambahan satu atau lebih zat gizi (nutrient) ke dalam suatu bahan pangan (Ramakrishnan, 2001).

Alternatif yang dapat dilakukan untuk mengurangi defisiensi zat besi yaitu dengan melakukan intervensi berbasis makanan pada camilan anak-anak. Cookies merupakan salah satu jenis camilan atau makanan ringan yang banyak disukai oleh sebagian besar masyarakat mulai balita sampai dewasa. Sebagai bahan pangan kering, cookies tergolong tidak mudah rusak dan mempunyai umur simpan yang relatif panjang (Suarni, 2009).

Diantara beberapa sayuran yang termasuk ke dalam sumber makanan yang mengandung zat besi tinggi seperti kentang yang mengandung Fe sebesar $1,9 \mathrm{mg} / 100 \mathrm{~g}$, labu sebesar $1,4 \mathrm{mg} / 100 \mathrm{~g}$, asparagus sebesar 2,2 mg/6 batang, buah bit sebesar 1,6 mg/g, dan bayam yang mempunyai kandungan Fe cukup tinggi yaitu sebesar 3,9 mg/100 g (Hadisoeganda, 1996). Selain itu, bayam juga kaya serat, harganya murah, dan siklus pemanenannya sangat cepat (2 minggu) (Hadisoeganda, 1996). Oleh karena itu, produk yang dihasilkan dari penambahan bayam diharapkan memiliki kadar Fe yang tinggi, baik untuk dikonsumsi anak-anak, dan dapat dijangkau oleh seluruh lapisan masyarakat. Selain itu, bayam juga mengandung vitamin $\mathrm{C}$ yang cukup tinggi yaitu $80 \mathrm{mg} / 100 \mathrm{~g}$ (Andasuryani dkk 2017).

Dalam bayam, sekurang-kurangnya terdapat 13 flavonoid yang berfungsi sebagai antioksidan, antibakteri, dan agen antikanker. Golongan senyawa fenolik dalam bayam seperti asam galat, asam cafeat, rutin, asam ferulat dan quecertin memiliki struktur yang berperan menangkap radikal bebas (Paranthaman et al., 2012).

Vitamin C sangat berperan dalam absorbsi zat besi yaitu meningkatkan absorbsi zat besi hingga empat kali lipat (Argana dkk, 2004) dan 3-6 kali lipat (Kuswardhani, 2003). Bioavailabilitas zat besi meningkat bila dikonsumsi bersama dengan vitamin $\mathrm{C}$, karena vitamin $\mathrm{C}$ akan mereduksi $\mathrm{Fe}^{3+}$ menjadi $\mathrm{Fe}^{2+}$ sehingga lebih mudah diserap oleh tubuh (WHO \& FAO, 2004). Vitamin C merupakan promotor yang kuat terhadap penyerapan zat besi dari makanan dan dapat melawan efek penghambat dari tanin dan fitat. Selain itu vitamin $\mathrm{C}$ membentuk gugus zat besi-askorbat yang tetap larut pada $\mathrm{pH}$ tinggi di dalam duodenum (Almatsier, 2006).

Salah satu buah yang mengandung vitamin $\mathrm{C}$ tinggi adalah tomat, yaitu sebesar $40 \mathrm{mg} / 100 \mathrm{~g}$. Kandungan senyawa dalam buah tomat diantaranya solanin $(0,007 \%)$, saponin, asam folat, asam malat, asam sitrat, bioflavonoid (termasuk likopen, $\alpha-$ karoten dan $\beta$-karoten) dan histamin. Likopen merupakan salah satu kandungan kimia paling banyak dalam tomat, dalam $100 \mathrm{~g}$ tomat rata-rata mengandung likopen sebanyak 3-5 mg (CaneneAdam dkk, 2004).

Penambahan bayam dalam pembuatan cookies telah dilakukan oleh Kuswardhani dkk (2003). Berdasarkan hasil uji daya terima, cookies masih diterima oleh panelis hingga penambahan bayam $10 \%$ dan merupakan formula terbaik pada sifat kimia dan fisika yang mana karakteristik cookies masih memenuhi SNI-01-2973-1992 tentang syarat mutu cookies.

Pada penelitian ini akan dilakukan penambahan tomat pada cookies bayam hijau. Tomat akan menyumbang vitamin $\mathrm{C}$ yang berperan memaksimalkan penyerapan zat besi dalam tubuh. Fortifikasi $\mathrm{Fe}$ dari bayam serta penambahan vitamin C dari tomat dalam pembuatan cookies diharapkan menjadikan cookies sebagai pangan yang dapat membantu memenuhi kebutuhan zat besi anak-anak pada khususnya dan mampu menjadi camilan bergizi di kalangan masyarakat pada umumnya.

\section{Bahan dan Metode}

\subsection{Bahan}

Bahan utama yang digunakan dalam penelitian ini ialah tepung terigu "segitiga biru", gula halus, margarin "menara", kuning telur, baking powder, garam "revina" yang diperoleh dari Toko Ramajaya, Surakarta. Bayam dan Tomat yang diperoleh dari Pasar Jaten, Karanganyar. Aquabidest, asuades, asam borat, $\mathrm{NaOH}, \mathrm{HCL}$, reagen MRMB, petroleum eter, etanol dan $\mathrm{H}_{2} \mathrm{SO}_{4}$. 


\subsection{Alat}

Alat utama yang digunakan dalam pembuatan cookies bayam hijau dengan penambahan ialah mixer cosmos, oven, loyang, baskom dan spatula. Sedangkan alat untuk analisis meliputi spektrofotometer UV-Vis UV-2450 (Shimadzu, Jepang), Universal Testing Machine (UTM) (Brookfield, Indonesia), alat ekstraksi soxhlet, botol timbang, desikator, oven, neraca analitik, labu kjeldahl, tanur, labu takar, tabung reaksi, erlenmeyer dan gelas beker.

\subsection{Metode}

\subsubsection{Pembuatan bubur bayam}

Pembuatan bubur bayam diawali dengan pemotongan batang dan akar bayam. Kemudian bayam yang telah dipotong dibersihkan dengan air yang mengalir. Bayam ditiriskan, dilakukan blanching selama 5 menit dengan suhu $98^{\circ}$ C. Bayam yang telah di blanching kemudian dihaluskan dengan blender.

\subsubsection{Pembuatan bubur tomat}

Pembuatan bubur tomat diawali dengan pembersihan tomat dengan air mengalir. Tomat yang digunakan ialah tomat yang telah matang optimum (berwarna merah). Kemudiam dilakukan pengelupasan pada kulit tomat. Tomat yang telah dikelupas dibelah menjadi dua bagian, biji tomat dibuang. Setelah itu tomat dilakukan penghalusan dengan blender.

\subsubsection{Pembuatan cookies bayam hijau dengan penambahan tomat}

Proses pembuatan cookies diawali dengan mengocok margarin dan gula halus hingga membentuk krim. Kemudian ditambahkan kuning telur, garam dan baking powder sambil terus dikocok hingga adonan homogen. Setelah itu, ditambahkan tepung terigu dan dilakukan pengadukan (tanpa menggunakan mixer) hingga tercampur rata. Setelah homogen, ditambahkan bubur bayam dan bubur tomat dan diaduk kembali hingga homogen. Kemudian adonan dicetak dan dipanggang dalam oven suhu $180^{\circ} \mathrm{C}$ selama 40 menit.

\subsubsection{Analisis fisik, kimia dan organoleptik}

Analisis fisik yang digunakan yaitu kekerasan metode Universal Testing Machine (UTM) Universal Testing Machine (UTM) Brookfield, Indonesia, (Bourne et al, 2002). Analisis kimia yang digunakan antara lain kadar air metode thermogravimetri (AOAC, 2002), kadar abu metode kering (AOAC, 2002), kadar protein kjeldahl (AOAC, 2002), kadar karbohidrat by different (Winarno, 2002) kadar lemak ekstraksi soxhlet (AOAC, 2002), kadar zat besi AAS) spektrofotometer UV-Vis Shimadzu UV2450, Jepang, (Apriyantono et al., 1989), serat kasar metode asam basa (Sudarmadji dkk, 2010), kadar vitamin C. Sedangkan analisis organoleptik menggunakan metode uji kesukaan hedonik (ASTM, 1996).

\subsubsection{Analisis data}

Data analisis fisik, kimia dan organoleptik yang diperoleh dianalisis secara statistik dengan metode one-way ANOVA menggunakan Software IBM SPSS 23. Jika menunjukkan hasil yang signifikan maka dilanjutkan dengan uji beda nyata menggunakan Duncan's Multiple Range Test (DMRT) pada taraf signifikansi $\alpha=0,05$.

\section{Hasil dan Pembahasan}

Tabel 1 menunjukkan bahwa nilai Fmax formula C3 merupakan nilai Fmax tertinggi yang berarti bahwa cookies formula C3 mempunyai tekstur yang keras. Tingkat kekerasan cookies menunjukkan bahwa semakin tinggi penambahan tomat maka nilai Fmax yang dihasilkan semakin tinggi pula, yang berarti bahwa cookies yang dihasilkan semakin keras. Walcott (1982) dalam Barrett et al (1998), menyatakan bahwa tomat mempunyai total padatan terlarut $10-20 \%$. Menurut Saltveit (2005) dalam Romalasari (2011) menyatakan bahwa secara umum komponen utama dalam padatan terarut adalah gula, yang mana padatan terlarut yang tinggi akan menyebabkan massa dan densitas suatu produk menjadi tinggi pula. Menurut Altan et al., (2007) densitas yang tinggi akan meningkatkan tingkat kekerasan suatu produk. Sehingga penambahan tomat yang tinggi pada cookies, akan meningkatkan tingkat kekerasannya.

Tabel 1

Nilai Fmax Cookies Bayam Hijau (Amaranthus tricolor L) dengan Penambaham Tomat (Solanum lycopersicum)

\begin{tabular}{cc}
\hline Formula & Fmax (N) \\
\hline C0 & $3,48^{\mathrm{a}} \pm 0,81$ \\
C1 & $4,37^{\mathrm{a}} \pm 1,87$ \\
C2 & $4,53^{\mathrm{b}} \pm 6,48$ \\
C3 & $5,89^{\mathrm{c}} \pm 2,69$ \\
\hline
\end{tabular}

Keterangan: Angka pada kolom yang sama diikuti superskrip yang sama menunjukkan tidak berbeda nyata $(\alpha<0,05)$

Formula Cookies Bayam + Tomat : $\mathrm{C} 0=$ tomat $0 \%, \mathrm{C} 1=$ tomat $15 \%, \mathrm{C} 2=$ tomat $25 \%, \mathrm{C} 3=$ tomat $35 \%$.

\subsection{Sifat fisik cookies bayam hijau dengan penambahan tomat}

Kekerasan cookies dikontribusi oleh bahan dalam pembuatan cookies seperti struktur amilosaamilopektin pada tepung terigu dan protein pada telur juga mempunyai peranan dalam membentuk kekerasan cookies (Barrett et al., 1998). Menurut 
Citation: Yudhistira, B., Sari, T.R., dan Affandi, D.R. (2019). Karakteristik Fisik, Kimia dan Organoleptik Cookies Bayam Hijau (Amaranthus tricolor) dengan Penambahan Tomat (Solanum lycopersicum) sebagai Upaya Pemenuhan Defisiensi Zat Besi pada Anak-Anak. Warta IHP, 36(2),83-95

Halaman | 86

Seyhun et al (2003), kekerasan remah dapat dikaitkan dengan re-kristalisasi amilosaamilopektin untuk membentuk kompleks antara pati dengan protein dan terjadi redistribusi air pada produk. Menurut Pradipta dan Putri (2015), tepung terigu mempunyai kandungan amilosa sebanyak $28 \%$ dan amilopektin sebanyak 72\%. Amilosa mempunyai sifat mudah menyerap dan melepas air. Sedangkan amilopektin mempunyai sifat sulit menyerap air namun air akan tertahan bila sudah terserap. Kandungan amilopektin yang lebih tinggi pada tepung terigu akan menyebabkan pati lebih basah, lengket dan cenderung sedikit menyerap air, sehingga kadar air produk menjadi rendah dan tekstur yang dihasilkan semakin keras (Wirakartakusumah et al., 1984 dalam Witono dkk 2012). Faktor lain yang berpengaruh terhadap kekerasan produk yaitu struktur sampel yang tidak teratur, denaturasi protein, kehilangan kapasitas menahan air dan terjadi koagulasi (Pereira et al, 2013).

Namun, kekerasan pada cookies ini tidak sepenuhnya disuplai oleh tomat, tetapi juga bahanbahan pembuatan cookies seperti protein pada telur dan amilosa-amilopektin pada tepung terigu yang digunakan.

\subsection{Sifat kimia cookies bayam hijau dengan penambahan tomat}

\subsubsection{Kadar Air}

Berdasarkan Tabel 2 dapat diketahui bahwa kadar air cookies C0 (3,15\%), lebih tinggi dari cookies formula C1 $(2,93 \%)$, C2 $(2,66 \%)$ dan lebih rendah dari formula C3 $(3,47 \%)$. Menurut SNI-012973-1992 kadar air cookies yang dianjurkan yaitu maksimal 5\% (BSN, 1992). Seluruh formula cookies (C0, C1, C2 dan C3) memiliki kadar air kurang dari $5 \%$ yang berarti bahwa kadar air seluruh formula cookies telah memenuhi syarat SNI-01-2973-1992 yang telah ditetapkan.

Kadar air cookies yang dihasilkan cenderung mengalami penurunan antara formula $\mathrm{C} 0-\mathrm{C} 2$. Hal ini dikarenakan formula C0 merupakan formula tanpa penambahan tomat namun pada formula C0 dilakukan penambahan air 35\% sehingga diperoleh kadar air yang tinggi dan cenderung menurun pada formula C2 karena pada formula C2 penambahan air berkurang. Pada formula C3 kadar air cookies mengalami kenaikan. Formula C3 merupakan formula cookies dengan penambahan tomat paling banyak. Menurut Firmanto (2011), tomat mengandung kadar air yang tinggi, yaitu 94 mg/100 gram bahan. Sehingga penambahan tomat yang tinggi menyebabkan kadar air yang cenderung tinggi pula pada cookies yang dihasilkan. Penambahan pada cookies dengan bahan koro pedang dan jagung dapat menurunkan kadar air (Basito et al, 2013).

\subsubsection{Kadar abu}

Berdasarkan Tabel 2 terlihat bahwa nilai kadar abu cookies bayam hijau dengan penambahan tomat berkisar antara 1,32\%-1,41\%. Menurut SNI-012973-1992, cookies mengandung kadar abu maksimum 2\% (BSN, 1992). Kadar abu cookies bayam hijau dengan penambahan tomat menunjukkan hasil kurang dari $2 \%$ pada semua formula, sehingga cookies telah memenuhi syarat SNI-01-2973-1992 yang telah ditetapkan.

Abu pada cookies dikontribusi oleh bahan yang digunakan dalam pembuatan cookies, terutama tomat. Menurut Sainju et al (2003), buah tomat kaya akan mineral seperti potassium $27 \mathrm{mg} / 100$ gram, kalsium $13 \mathrm{mg} / 100$ gram, natrium $3 \mathrm{mg} / 100$ gram, dan besi 0,5 mg/ 100 gram. Menurut Suarez et al., jenis tomat, menyatakan bahwa kadar abu pada buah tomat berkisar antara 0,59\%-0,65\%.

Tabel 2

Karakteristik Kimia Cookies Bayam Hijau (Amaranthus tricolor L) dengan Penambaham Tomat (Solanum lycopersicum)

\begin{tabular}{|c|c|c|c|c|c|}
\hline \multirow{2}{*}{ Parameter } & \multirow{2}{*}{ Satuan } & \multicolumn{4}{|c|}{ Formula } \\
\hline & & $\mathrm{CO}$ & $\mathrm{C} 1$ & $\mathrm{C} 2$ & C3 \\
\hline Air & $\% \mathrm{bb}$ & $3,15^{\mathrm{b}} \pm 0,06$ & $2,93^{\mathrm{ab}} \pm 0,001$ & $2,66^{\mathrm{a}} \pm 0,18$ & $3,47^{c} \pm 0,07$ \\
\hline \multirow[t]{2}{*}{$\mathrm{Abu}$} & $\% \mathrm{bk}$ & $1,35^{\mathrm{a}} \pm 0,001$ & $1,42^{\mathrm{a}} \pm 0,04$ & $1,45^{a} \pm 0,08$ & $1,48^{a} \pm 0,01$ \\
\hline & $\%$ bb & $1,32^{\mathrm{a}} \pm 0,03$ & $1,38^{\mathrm{a}} \pm 0,04$ & $1,41 \mathrm{a} \pm 0,07$ & $1,38^{a} \pm 0,01$ \\
\hline \multirow[t]{2}{*}{ Lemak } & $\% \mathrm{bk}$ & $21,51^{\mathrm{a}} \pm 1,69$ & $24,16^{\mathrm{ab}} \pm 1,48$ & $24,29^{\mathrm{ab}} \pm 1,12$ & $25,46^{b} \pm 0,29$ \\
\hline & $\%$ bb & $21,08 \mathrm{a} \pm 0,88$ & $23,33^{\mathrm{ab}} \pm 1,42$ & $23,35^{a b} \pm 1,08$ & $24,80^{\mathrm{b}} \pm 0,28$ \\
\hline \multirow[t]{2}{*}{ Protein } & $\% \mathrm{bk}$ & $7,60^{a} \pm 0,16$ & $7,57 \mathrm{a} \pm 0,27$ & $7,62^{\mathrm{a}} \pm 0,27$ & $7,73^{a} \pm 0,16$ \\
\hline & $\%$ bb & $7,40 \mathrm{a} \pm 0,13$ & $7,35^{\mathrm{a}} \pm 0,27$ & $7,43 \mathrm{a} \pm 0,26$ & $7,46^{a} \pm 0,15$ \\
\hline \multirow[t]{2}{*}{ Karbohidrat } & $\%$ bk & $65,75^{\mathrm{b}} \pm 1,80$ & $63,03^{\mathrm{ab}} \pm 1,28$ & $62,83^{\mathrm{ab}} \pm 0,72$ & $60,53^{a} \pm 0,05$ \\
\hline & $\%$ bb & $68,35^{b} \pm 1,35$ & $67,07 \mathrm{ab} \pm 1,62$ & $66,52^{\mathrm{ab}} \pm 1,29$ & $65,03^{\mathrm{a}} \pm 0,44$ \\
\hline Serat kasar & $\% \mathrm{bk}$ & $0,88^{a} \pm 0,01$ & $0,89^{a} \pm 0,03$ & $1,15^{\mathrm{b}} \pm 0,02$ & $1,33^{c} \pm 0,02$ \\
\hline Vitamin C & $\%$ & $0,07 a \pm 0,001$ & $0,12^{\mathrm{b}} \pm 0,10$ & $0,15^{\mathrm{b}} \pm 0,04$ & $0,23^{c} \pm 0,23$ \\
\hline Kadar Fe & ppm & $47,89^{b} \pm 0,46$ & $44,12^{\mathrm{ab}} \pm 3,94$ & $40,76^{a} \pm 0,21$ & $64,79^{c} \pm 0,75$ \\
\hline
\end{tabular}

Keterangan : Angka pada baris yang sama diikuti superskrip yang sama menunjukkan tidak berbeda nyata $(\alpha<0,05)$

Formula Cookies Bayam + Tomat : C0 = tomat $0 \%, \mathrm{C} 1=$ tomat $15 \%, \mathrm{C} 2=$ tomat $25 \%, \mathrm{C} 3=$ tomat $35 \%$. 
Bahan lain yang berkontribusi terhadap kadar abu cookies yaitu bayam. Bayam memiliki kandungan mineral antara lain kalsium 276 $\mathrm{mg} / 100$ gram, fosfor $67 \mathrm{mg} / 100$ gram dan zat besi 3,9 mg/100 gram (Kementrian Kesehatan Republik Indonesia) dan memiiki kadar abu 0,63,1\% (Fatimah, 2009). Selain itu, menurut Oktavia (2008), berbagai bahan dapat berkontribusi terhadap jumlah kadar abu cookies salah satunya adalah kuning telur. Semakin banyaknya kandungan mineral yang dikandung di dalam bahan baku, maka akan semakin banyaknya kadar abu yang terdapat di dalam bahan tersebut. Tinggi rendahnya kadar abu suatu bahan antara lain disebabkan oleh kandungan mineral yang berbeda pada sumber bahan baku dan juga dapat dipengaruhi oleh proses demineralisasi pada saat pembuatan (Rizky, 2013). Penlitian Luthfi et al (2017), pembuatan cookies dengan penambahan bubur bayam merah tidak berpengaruh nyata terhadap kadar abu cookies.

\subsubsection{Kadar lemak}

Berdasarkan Tabel 2 dapat diketahui bahwa cookies formula C0 mempunyai kadar lemak yang lebih rendah dari cookies formula C3. Hal ini dikarenakan formula C3 merupakan cookies dengan penambahan tomat paling banyak, yang mana menurut Yani dan Ade (2004), tomat mengandung lemak sebanyak 0,3 gram/100 gram bahan yang dapat berkontribusi terhadap kandungan lemak pada cookies.

Kandungan lemak pada cookies bayam hijau dengan penambahan tomat berkisar 21,08\%24,80\%. Kadar lemak cookies telah sesuai dengan SNI-01-2973-1992 yang menyatakan bahwa kadar lemak pada cookies minimum 9,5\% (BSN, 1992). Kadar lemak yang cukup tinggi pada cookies bayam hijau disebabkan karena penambahan margarin pada proses pembuatannya yakni $\pm 19,5 \%$ dari berat total adonan. Lemak pada cookies dikontribusi oleh penambahan margarin, dan kuning telur yang termasuk bahan dengan kandungan lemak yang tinggi. Jumlah asam lemak margarin $50 \%$ yang terdapat dalam bentuk lipoprotein (Lingga, 2012), yang mana bila ditambahkan dalam adonan, menyebabkan cookies mempunyai kadar lemak yang tinggi ditambah dengan lemak yang terkandung pada kuning telur 31-32\% (Hendrasty, 2013).

\subsubsection{Kadar protein}

Tabel 2 menunjukkan bahwa kadar protein cookies tidak berbeda nyata pada semua formula. Menurut Firmanto (2011), tomat memiliki kandungan protein 1 gram/100 gram bahan yang juga menyuplai kandungan protein pada cookies yang dihasilkan. Kadar protein pada cookies berkisar antara 7,35\%-7,46\%. Menurut SNI-01-
2973-1992 tentang standar mutu cookies menyebutkan bahwa kadar protein cookies minimum 6\% (BSN, 1992). Hasil uji kadar protein menunjukkan bahwa semua formula cookies bayam hijau dengan penambahan tomat telah sesuai dengan SNI-01-2973-1992 yang telah ditetapkan.

Kandungan protein pada cookies yang dihasilkan dikontribusi dari bahan-bahan pembuatan cookies seperti bayam, telur dan terigu yang mempunyai kandungan protein tidak terlalu tinggi. Bayam mempunyai kandungan protein 3,5 gram/100 gram (Kementrian Kesehatan Republik Indonesia, telur mempunyai kandungan protein 12,9\% (Komala, 2008), dan menurut Astawan (2004) tepung terigu yang digunakan dalam pembuatan cookies termasuk ke dalam terigu berprotein rendah dengan kandungan protein 7 9\%. Sehingga pada cookies bayam hijau dengan penambahan tomat ini dihasilkan kandungan protein yang tidak terlalu tinggi.

\subsubsection{Kadar karbohidrat}

Tabel 2 menunjukkan bahwa kadar karbohidrat cookies formula C0 lebih tinggi daripada formula C3. Kadar karbohidrat cookies bayam hijau dengan penambahan tomat berkisar antara 65,03\%-68,35\%. Menurut SNI-01-29731992, cookies mempunyai kadar karbohidrat minimum 70\% (BSN, 1992). Hasil analisis kadar karbohidrat menunjukkan bahwa kadar karbohidrat cookies bayam hijau dengan penambahan tomat memiliki nilai yang lebih rendah dari kadar karbohidrat yang ditetapkan SNI. Kadar karbohidrat cookies bayam hijau dengan penambahan tomat hanya berkisar 60,57\%-65,77\%. Penambahan tomat pada cookies memberikan pengaruh terhadap kadar kabohidrat cookies, semakin banyak penambahan tomat pada cookies cenderung menyebabkan kadar karbohidrat cookies menurun. Hal ini disebabkan karena karbohidrat tomat yang cukup rendah yaitu 4,2 mg / 100 gram. Kadar karbohidrat pada tomat terdapat dalam bentuk serat sebesar 1 gram/ 100 gram (Kusharto, 2006) dan pektin berkisar antara 0,17\%-0,25\% (Anggraeni, 2012).

Menurut Kuswardhani dkk (2003), penambahan bayam berpengaruh nyata terhadap kadar karbohidrat. Secara umum bayam menyebabkan penurunan kadar karbohidrat karena kadar karbohidrat bayam yang rendah yaitu 6,5 \%. Selain itu, menurut Fatkurahman dkk (2012), kadar karbohidrat yang dihitung secara by difference dipengaruhi oleh komponen nutrisi lain, semakin rendah komponen nutrisi lain maka kadar karbohidrat semakin tinggi. Begitu juga sebaliknya semakin tinggi komponen nutrisi lain, maka kandungan karbohidrat akan semakin rendah. Komponen nutrisi yang mempengaruhi 
Citation: Yudhistira, B., Sari, T.R., dan Affandi, D.R. (2019). Karakteristik Fisik, Kimia dan Organoleptik Cookies Bayam Hijau (Amaranthus tricolor) dengan Penambahan Tomat (Solanum lycopersicum) sebagai Upaya Pemenuhan Defisiensi Zat Besi pada Anak-Anak. Warta IHP, 36(2),83-95

Halaman | 88

besarnya kandungan karbohidrat antara lain protein, air, lemak, abu dan serat kasar.

\subsubsection{Serat kasar}

Berdasarkan Tabel 2 dapat diketahui bahwa kadar serat kasar cookies formula C0 (0,85\%), lebih rendah dari cookies formula C2 (1,15\%) dan formula C3 (1,33\%). Formula C3 mempunyai kadar serat kasar yang paling tinggi. Formula C3 merupakan formula cookies dengan penambahan tomat paling banyak. Menurut Kusharto (2006), tomat mengandung serat kasar sebesar 1 gram/ 100 gram bahan, sehingga semakin banyak penambahan tomat, kadar serat kasar cookies juga akan meningkat. Kadar serat kasar yang meningkat juga disebabkan oleh penggunaan tomat yang berupa buah segar, yang mengandung serat alami sehingga jumlah serat kasarnya lebih banyak (Millah dkk, 2013). Kadar serat kasar pada cookies juga dikontribusi oleh kandungan serat pada bayam yaitu sebesar 0,8 gram $/ 100$ gram bahan (Kementrian Kesehatan Republik Indonesia). Menurut Tensiska (2008), serat kasar adalah komponen hasil hidrolisis suatu bahan pangan dengan asam kuat selanjutnya dihidrolisis selulosa sekitar 50\% dan hemiselulosa $85 \%$. Penambahan bayam dapat meningkatkan serat kasar pada marsmallow sebesar 0.079-0.160\% (Yudhistira et al, 2017). Sumber serat lain yang dapat digunakan yaitu rumput laut, menurut Rehen dan Ivakdalam (2019) dan Kesuma dkk (2015) penambahan rumput laut berpengaruh nyata terhadap serat kasar cookies serta pada biskuit yang dilakukan Suparmi dan Sahri (2009).

Penambahan tepung biji rami mentah dan panggang dengan pengkayaan lignin dan serat pangan dalam cookies meningkatkan sifat nutraceutical dan mengembangkan produk kesehatan bergizi (Kaur et al, 2019). Selain serat kandungan pati resistan yang tinggi dari tepung pisang menurun secara signifikan setelahnya pemrosesan hidrotermal konvensional, seperti pemanggangan (Sanchez-Riveraa et al, 2019).

\subsubsection{Vitamin $C$}

Dari Tabel 2 dapat diketahui bahwa kadar vitamin C cookies berkisar antara 0,07\%-0,23. Formula C3 mempunyai kadar vitamin C yang paling tinggi, hal ini karena formula C3 merupakan formula cookies dengan penambahan tomat paling tinggi, yaitu 35\%. Menurut Firmanto (2011) tomat mengandung vitamin C $40 \mathrm{mg} / 100$ gram bahan yang dapat menyuplai kandungan vitamin $\mathrm{C}$ pada cookies tersebut.

Kandungan vitamin C dalam cookies disuplai sepenuhnya oleh adanya bayam dan tomat. Menurut Yadav dan Shegal (1995), bayam yang diblanching mempunyai kandungan vitamin C 299,7 mg/100 gram. Namun pada Tabel 2 dapat diketahui bahwa kandungan vitamin C cookies hanya berkisar antara 0,07-0,23\% lebih rendah dari total vitamin $\mathrm{C}$ tomat dan bayam. Yang mana apabila ditotal kandungan vitamin $\mathrm{C}$ dalam tomat dan bayam adalah 339,7 mg/100 gram atau berkisar 0,339\%.

Proses pemanggangan merupakan salah satu faktor yang sangat berpengaruh terhadap kandungan vitamin $\mathrm{C}$ cookies. Selain itu, proses penghancuran bayam dan tomat dengan blender juga mengakibatkan kadar vitamin $C$ berkurang. Menurut Putri dan Setiawati (2015), vitamin C merupakan vitamin yang mudah larut dalam air, oleh karena itu pada waktu mengalami penirisan, pencucian dan perebusan bahan makanan yang mengandung vitamin $\mathrm{C}$, akan mengalami penurunan kadarnya. Pada proses pembuatan cookies ini, kandungan vitamin $\mathrm{C}$ mengalami penurunan yang disebabkan oleh proses pemanggangan dan proses penghancuran tomat dengan blender, sehingga akan menghasilkan kandungan vitamin $\mathrm{C}$ yang tidak maksimal pada produk cookies. Selain itu penurunan kandungan vitamin $\mathrm{C}$ pada cookies diduga disebabkan karena konsentrasi tomat yang ditambahkan lebih rendah dari total adonan cookies, sehingga akan diperoleh kadar vitamin C yang lebih rendah pula pada sampel C1 (15\%) sebesar 0,12\% dan C2 (35\%) dengan kadar vitamin C yaitu 0,15\%.

Vitamin C berguna untuk membantu penyerapan besi sehingga absorbsi akan lebih banyak dalam usus. Sebagai reduktan, vitamin C mereduksi cupri (Cu2+) menjadi cuprus $(\mathrm{Cu}+)$ dan ion ferri $(\mathrm{Fe} 3+)$ menjadi ion ferrous $(\mathrm{Fe} 2+)$ yang akan berpengaruh terhadap penyerapannya di usus halus dan dengan demikian memberikan efek yang menguntungkan (Jourkesh et al, 2011).

\subsubsection{Kadar zat besi}

Cookies formula C3 mempunyai kadar Fe paling tinggi yaitu $64,79 \mathrm{ppm}$ atau $6,479 \mathrm{mg} / 100$ gram. Formula C3 merupakan formula cookies dengan penambahan tomat paling banyak. Menurut Firmanto (2011) tomat mempunyai kandungan $\mathrm{Fe}$ 0,5 mg/100 gram, sehingga peningkatan jumlah tomat pada pembuatan cookies juga akan meningkatkan kandungan Fe nya.

Kadar Fe pada cookies bayam hijau dengan penambahan tomat dikontribusi oleh bahan penyusunnya. Selain tomat, bayam juga mempunyai kandungan $\mathrm{Fe}$ 3,9 mg/100 gram bahan (Kuswardhani dkk, 2003). Tepung terigu yang digunakan dalam pembuatan cookies mempunyai kandungan $\mathrm{Fe}$ 1,2 mg/100 gram (Daftar Komposisi Bahan Makanan, 2000) dan telur mempunyai kandungan $\mathrm{Fe} 1,83 \mathrm{mg} / 100$ gram bahan (USDA, 2007). Defisiensi zat besi dapat menyebabkan akibat yang fatal pada ibu 
hamil yaitu keguguran, partus prematus, inersia uteri, partus lama, atonia uteri dan menyebabkan perdarahan serta syok (Agarwal et al., 2013). Bayam dapat meningkatkan kadar hemoglobin ibu hamil (Kundaryanti et al, 2018).

Berdasarkan Tabel 2 dapat diketahui bahwa kadar Fe cookies berkisar antara 40,76 ppm-64,79 ppm. Kadar Fe pada cookies bayam hijau dengan penambahan tomat lebih rendah jika dibandingkan total kandungan Fe cookies ditinjau dari bahan penyusunnya yaitu tomat, bayam, tepung terigu dan telur yang berjumlah 7,43 mg/100 gram atau 74,3 ppm. Penurunan kadar Fe cookies diduga karena perbedaan konsentrasi tepung terigu, telur, bayam dan tomat yang dicampurkan dalam bahan terhadap berat total bahan pada pembuatan cookies.

Parameter zat besi ini merupakan salah satu parameter yang penting karena zat besi merupakan garam mineral yang apabila dikonsumsi secara teratur dapat meningkatkan jumlah sel darah merah (Hidayah, 2012). Biofortifikasi karoten ubi jalar meningkatkan kualitas nutrisi dan sensorik cookies sorgum sehingga potensial sebagai makanan fungsional untuk mencegah atau mengendalikan anemia defisiensi besi (Infante et al, 2017).

\subsection{Sifat organoleptik cookies bayam hijau dengan penambahan tomat}

Tabel 3.

Skor Kesukaan terhadap Parameter Mutu Cookies Bayam Hijau (Amaranthus tricolor $L$ ) dengan Penambaham Tomat (Solanum lycopersicum)

\begin{tabular}{cccccc}
\hline \multirow{2}{*}{ Formula } & \multicolumn{5}{c}{ Atribut Oranoleptik } \\
\cline { 2 - 6 } & Warna & Aroma & Rasa & Tekstur & Keseluruhan \\
\hline C0 & $5,17^{\mathrm{b}}$ & $5,20^{\mathrm{b}}$ & $5,33^{\mathrm{b}}$ & $5,37^{\mathrm{b}}$ & $5,43^{\mathrm{b}}$ \\
C1 & $4,53^{\mathrm{a}}$ & $4,73^{\mathrm{a}}$ & $4,77^{\mathrm{a}}$ & $5,27^{\mathrm{b}}$ & $5,10^{\mathrm{ab}}$ \\
C2 & $4,83^{\mathrm{ab}}$ & $4,70^{\mathrm{a}}$ & $5,37^{\mathrm{b}}$ & $5,33^{\mathrm{b}}$ & $5,07^{\mathrm{ab}}$ \\
C3 & $4,70^{\mathrm{a}}$ & $4,73^{\mathrm{a}}$ & $4,60^{\mathrm{a}}$ & $4,73^{\mathrm{a}}$ & $4,83^{\mathrm{a}}$ \\
\hline
\end{tabular}

Keterangan : Angka pada kolom yang sama diikuti superskrip yang sama menunjukkan tidak berbeda nyata $(\alpha<0,05)$

Formula Cookies Bayam + Tomat : $\mathrm{C} 0=$ tomat $0 \%, \mathrm{C} 1=$ tomat $15 \%, \mathrm{C} 2=$ tomat $25 \%, \mathrm{C} 3=$ tomat $35 \%$

Skor : 1 = sangat tidak suka, 2 = tidak suka, 3 = agak tidak suka, 4 = agak suka, $5=$ suka, $6=$ sangat suka

\subsubsection{Warna}

Berdasarkan Tabel 3 formula C0 lebih disukai pada parameter warna daripada formula C3. Cookies formula C0 lebih disukai oleh panelis karena memiliki warna hijau cerah disertai warna kecoklatan. Warna hijau dari cookies dihasilkan oleh kandungan klorofil pada bayam yang digunakan. Menurut Winarno (2002), klorofil merupakan pigmen berwarna hijau yang terdapat dalam kloroplas bersama-sama dengan karoten dan xantofil. Sedangkan warna kecoklatan berasal dari karamelisasi dan reaksi maillard.

Semakin tinggi tomat yang ditambahkan, warna cookies yang dihasilkan menjadi coklat kemerahan. Warna kecoklatan pada cookies sendiri terbentuk karena terjadinya karamelisasi dan reaksi maillard ketika proses pemanggangan cookies berlangsung. Menurut Winarno (2002), warna coklat yang ditimbulkan pada cookies disebabkan karena pada proses pemanggangan adonan terjadi reaksi maillard dan karamelisasi. Amri dkk (2015) menyatakan titik lebur sukrosa mencapai $140^{\circ} \mathrm{C}$ agar terjadi karamelisasi.

Sedangkan warna kemerahan yang terbentuk pada produk cookies dipengaruhi oleh kandungan likopen yang terdapat pada buah tomat. Menurut Shi dan Maguer (2000), karakteristik warna merah pada tomat matang disebabkan oleh kandungan likopennya. Tomat dianggap sebagai sumber utama likopen yang menyumbang karotenoid. Likopen merupakan pigmen alami dalam tomat yang akan menghasilkan warna kemerahan pada produk yang dihasilkan. Zat pewarna alami yang aman digunakan yaitu dari golongan karotenoid (Saati, 2014). Selain itu flavonoid juga dapat ditambahkan dari umbiumbian seperti ubi jalar (Subandoro et al, 2013). Tartary buckwheat malt dapat digunakan untuk meningkatkan polifenol dan kandungan flavonoid dan kapasitas antioksidan glutenfree cookies dibandingkan dengan tepung beras dan gandum (Molinari et al, 2018). Biji rami (flaxseed) dapat ditambahkan hingga kadar 10\% untuk tepung terigu dengan tingkat penerimaan yang cukup baik sebagai alternatif yang bergizi, kaya antioksidan dan sehat bagi konsumen (Kaur et al, 2017). Karakteristik kimia dari cookies dipengaruhi oleh suhu, sedangkan sifat warna sebagian besar dipengaruhi oleh posisi permukaan sampel (Pestoric et al, 2017). Selain itu penambahan glutathione murni menghambat reaksi Maillard, dan meningkatkan sifat fisikokimia dari adonan dan cookies (Oztürk et al, 2017).

\subsubsection{Aroma}

Berdasarkan Tabel 3 dapat diketahui bahwa formula C0 merupakan formula yang paling disukai oleh panelis. Hal ini dikarenakan formula C0 merupakan formula tanpa penambahan tomat. Menurut Kuswardhani (2003), bayam yang digiling dengan blender mengeluarkan aroma yang khas, selain itu proporsi bahan lain yang digunakan untuk membuat adonan cookies yang sama sehingga aroma khas bayam akan memberikan pengaruh terhadap aroma produk akhir.

Selain aroma khas bayam, cookies yang dihasilkan juga memberikan aroma enak yang berasal dari bahan tambahan dalam pembuatan cookies. Menurut Alvionita dkk (2015), aroma cookies juga ditentukan oleh perpaduan antara bahan-bahan komponen pembuatan cookies. Komponen pada adonan menimbulkan bau khas, 
misalnya pencampuran margarin, gula dan telur yang mempunyai aroma yang disukai panelis. Selain itu menurut Martunis (2012), aroma dapat disebabkan karena adanya proses reaksi maillard. Dimana adanya reaksi maillard selama pemanggangan menghasilkan aroma produk yang khas dan disukai.

Formula cookies dengan penambahan tomat menujukkan nilai kesukaan berkisar antara 4,704,73 yang berarti bahwa pada atribut aroma cookies dengan penambahan tomat memiliki rentang nilai agak disukai. Ada aroma langu dari tomat pada cookies yang dihasilkan sehingga menyebabkan panelis tidak memberikan penilaian sampai rentang suka (Iswari K, 2015). Aroma merupakan parameter yang paling banyak menentukan terkait kelezatan suatu pangan, sehingga menentukan penerimaan konsumen (Wahyuni, 2010). Penggunaan lemak pada cookies akan mempengaruhi pembentukan aroma (Setiyowati dan Nisa, 2014). Faktor selanjutnya yaitu kandungan amilosa, nilai aroma yang tinggi dipengaruhi nilai amilosa yang tinggi. Amilosa dengan kandungan sedang mempunyai karakteristik gel yang lunak dan afinitas terhadap senyawa volatile (aroma) (Mulyadi et al, 2014).

\subsubsection{Rasa}

Nilai kesukaan terhadap parameter rasa menujukkan nilai antara 4,60-5,37 yang berarti nilai kesukaan terhadap rasa memiliki rentang antara agak suka sampai suka. Rasa yang dihasilkan pada produk cookies bayam dengan penambahan tomat yaitu perpaduan antara rasa masam dari tomat dan rasa enak dari penambahan bahan lain, selain itu juga terdapat rasa khas bayam sebagai aftertaste dari rasa cookies.

Rentang nilai kesukaan yang dihasilkan pada parameter rasa dari agak suka sampai suka. Formula penambahan tomat paling rendah dan paling tinggi menunjukkan rentang kesukaan yang agak suka. Hal ini dikarenakan pada formula penambahan tomat paling rendah, rasa tomat pada cookies yang dihasilkan tidak terlalu menonjol. Sedangkan pada penambahan tomat paling tinggi, rasa cookies yang dihasilkan cenderung agak masam. Pada penambahan tomat 25\% menghasilkan cookies yang disukai panelis. Menurut Maulida dan Zulkarnaen (2010), tomat memiliki rasa yang khas dari masam hingga manis. Penambahan tomat $25 \%$ pada cookies menyebabkan cookies mempunyai rasa tomat yang pas dan tidak menimbulkan rasa masam yang berlebihan pada cookies yang dihasilkan.

Apriani (2010) juga menyatakan bahwa penambahan bahan seperti margarin dan telur akan mempengaruhi rasa pada cookies. Kandungan lemak dan protein pada adonan cukup membantu meningkatkan rasa dari produk yang dihasilkan. Selain sebagai pembentuk struktur, tepung juga berperan dalam pembentukan citarasa. Pada biskuit berbahan sorghum warna gelap disebabkan oleh kandungan tannin (Hubbard et al, 2009). Tepung almond terdelipidifikasi parsial yang tersisa dari ekstraksi minyak almond, digunakan sebagai bahan alternatif dalam proses cookies (Barreira et al, 2019). Penggunaan lemak atau minyak dapat meningkatkan aroma dan tekstur cookies.

\subsubsection{Tekstur}

Tabel 3 menunjukkan bahwa nilai kesukaan terhadap parameter tekstur menunjukkan nilai yang berkisar antara 4,73-5,37 yang berarti bahwa tingkat kesukaan panelis berada pada range agak suka sampai suka. Formula C3 dengan penambahan tomat 35\% menghasilkan cookies yang paling tidak disukai oleh panelis. Hasil uji organoleptik parameter tekstur telah sesuai dengan uji tekstur cookies dengan menggunakan alat Universal Testing Machine (UTM) dimana formula penambahan tomat paling banyak menghasikan tesktur yang keras dan tidak disukai oleh panelis. Tekstur dipengaruhi oleh bahan diantaranya tepung, gula dan kuning telur (Rohimah et al, 2013). Tekstur cookies dengan kandungan gluten yang rendah menyebabkan pengembangan dan pembentukan pori-pori semakin kecil, sehingga cookies yang dihasilkan menjadi keras (Kusuma, 2013). Cookies dengan penambahan mocaf dan koro menyebabkan tekstur menjadi keras (Saputra, 2104).

Bekatul oat dan bekatul gandum terdepinitasi pada cookies, menghasilkan rasio penyebaran yang lebih tinggi, tekstur lebih keras dan warna lebih gelap. Sensorik mereka nilai evaluasi cukup menjanjikan, terutama bekatul gandum yang difermentasi (Baumgartner et al, 2018). Inkorporasi xanthan gumVmenunjukkan retensi struktural yang tinggi karenaVmodulus geser yang tinggi, ekstrudabilitasnya yang rendah menghasilkan tinggi kekerasan ekstrusi (Kim et al, 2019). Dalam meningkatkan tekstur cookies dapat menggunakan tepung gandum malt sebagai alternatif untuk enzimatik improvers tanpa efek merugikan terkait dengan kelebihan aktivitas amilolitik (Yang et al, 2020).

\subsubsection{Keseluruhan}

Berdasarakan Tabel 3 dapat diketahui bahwa nilai kesukaan pada parameter keseluruhan tidak berbeda nyata antara semua formula. Skor yang dihasilkan berkisar antara 4,83-5,43 yang berarti penilaian panelis pada rentang agak suka sampai suka. Tingkat kesukaan pada parameter keseluruhan, menunjukkan cookies formula C2 dengan penambahan tomat $25 \%$ merupakan 
cookies yang disukai oleh panelis. Tingkat kesukaan ditinjau dari atribut rasa pada cookies formula C2 yang mana berbeda nyata dengan cookies C1 dan C3. Dengan demikian cookies yang terbaik dari hasil uji organoleptik pada parameter keseluruhan adalah cookies bayam hijau dengan penambahan tomat 25\%. Penggunaan bahan lain yaitu variasi guar gum (PHGG) terhidrolisis parsial, level air dan waktu pemanggangan dapat mempengaruhi sifat fisik dan sensorik (Mudgil et al, 2017).

3.4 Penentuan formulasi terbaik bayam hijau (Amaranthus tricolor L) dengan penambahan tomat (Solanum lycopersicum)

Proses pengambilan keputusan perlakuan terbaik dilakukan dengan indeks efektivitas (deGarmo dkk (1984) dalam Ernawati (2009)) Prinsip pengujiannya adalah memberikan bobot (score) sesuai dengan kontribusi suatu karakteristik terhadap formulasi yang dihasilkan. Semakin besar pengaruh suatu karakteristik terhadap formula terbaik yang dipilih, maka semakin besar pula nilai atau bobot yang diberikan terhadap karakteristik tersebut.

Berdasarkan nilai uji pembobotan karakteristik fisiki, kimia dan organoleptik cookies bayam hijau dengan penambahan tomat, dapat diketahui bahwa formula terbaik dengan nilai tertinggi adalah formula C2 yaitu cookies dengan penambahan tomat $25 \%$ dengan bobot 0,69 . Hal ini disebabkan oleh banyaknya nilai perlakuan terendah terdapat pada formula C1 dan C3 sehingga nilai efektivitasnya 0 dan nilai hasilnya rendah dibandingkan dengan nilai hasil formula C2. Oleh karena itu formula C2 cookies bayam hijau dengan penambahan tomat 25\% merupakan formula terbaik menurut karakterisik fisik, kimia dan organoleptik.

3.5 Nilai Acuan Label Gizi (ALG) cookies bayam hijau (Amaranthus tricolor L) dengan penambahan tomat (Solanum lycopersicum)

Acuan label gizi (ALG) merupakan acuan untuk pencantuman keterangan tentang kandungan gizi pada label produk pangan. Menurut Badan Pengawas Obat dan Makanan Republik Indonesia (2016), tentang pengawasan klaim pada label dan iklan pangan olahan, suatu vitamin atau mineral dikatakan memiliki zat gizi sumber apabila mengandung 15\% ALG per 100 gram (dalam bentuk padat) atau 7,5\% ALG per $100 \mathrm{ml}$ (dalam bentuk cair) dan dikatakan tinggi/kaya apabila produk mengandung vitamin/mineral 2x jumlah untuk "sumber".

Formula terbaik cookies bayam hijau dengan penambahan tomat, terdapat pada formula C2 yaitu cookies dengan penambahan tomat $25 \%$. Cookies C2 mempunyai kandungan vitamin C
0,15\% atau $150 \mathrm{mg} / 100$ gram dan kandungan $\mathrm{Fe}$ $40,76 \mathrm{ppm}$ atau 4,076 $\mathrm{mg} / 100$ gram. Vitamin C cookies dikatakan memiliki zat gizi "sumber" apabila mengandung minimum 13,5 mg/100 gram vitamin C pada sampel (15\% ALG vitamin C; $15 \%$ dari $90 \mathrm{mg}$ ) dan dikatakan "tinggi/kaya" apabila mengandung minimum $27 \mathrm{mg} / 100$ gram vitamin $\mathrm{C}$ pada sampel (2x jumlah sumber). Kadar $\mathrm{Fe}$ cookies dikatakan memiliki zat gizi "sumber" apabila mengandung minimum 3,3 mg/100 gram Fe pada sampel (15\% ALG zat besi; $15 \%$ dari 22 mg) dan dikatakan "tinggi/kaya" apabila mengandung minimum 6,6 mg/100 gram Fe pada sampel (2x jumlah sumber). Vitamin $\mathrm{C}$ cookies $\mathrm{C} 2$ termasuk ke dalam zat gizi tinggi/kaya karena mempunyai kandungan vitamin $\mathrm{C}$ lebih tinggi dari nilai ALG vitamin C "tinggi/kaya” yang dianjurkan. Sedangkan kadar Fe cookies termasuk ke dalam zat gizi sumber karena mempunyai kandungan $\mathrm{Fe}$ yang lebih tinggi dari nilai ALG zat besi "sumber" dan kandungan Fe yang lebih rendah dari nilai ALG zat besi "kaya/tinggi".

\section{Kesimpulan}

Penambahan tomat pada cookies bayam hijau menyebabkan cookies cenderung lebih disukai oleh panelis pada parameter aroma dan tekstur dengan skor 4,73. Secara keseluruhan konsentrasi penambahan tomat $15 \%$ dan $25 \%$ merupakan cookies yang paling disukai, dan tidak berbeda nyata dengan skor 5,10. Peningkatan penambahan tomat pada cookies bayam hijau menyebabkan peningkatan kekerasan (Fmax) dari 3,4 $\mathrm{N}$ menjadi $5,89 \mathrm{~N}$, serat kasar $0,88 \%$ menjadi $1,15 \%$, dan kadar vitamin $0,07 \%$ menjadi $0,15 \%$ C cookies. Berdasarkan nilai uji pembobotan, penambahan tomat 25\% merupakan formula terbaik cookies bayam hijau dengan penambahan tomat. (tomat $25 \%$ ) nilai acuan label gizi (ALG), cookies formula C2 mengandung Fe 40,76 ppm yang termasuk ke dalam sumber Fe.

\section{Daftar Pustaka}

Agarwal KN, V. Gupta, S. Agarwal. 2013. Effect of Maternal Iron Status On Placenta, Fetus And Newborn. International Journal of Medicine And Medical Sciences, 5 (9).

Almatsier, S. 2006. Prinsip Dasar Ilmi Gizi. Jakarta. Gramedia Pustaka Utama.

Altan, Aylin.,McCarthy, Kaththryn L., dan Maskan, Medeni. 2007. Evaluation of Snack Foods From Barley-Tomato Pomace Blends by Extrusion Processing. Journal of Food Engineering 84 : 231-242.

Alvionita, Vernanda P. Angkasa, Dudung dan Wijaya, Hendra. 2015. Pembuatan Cookies Bebas Gluten Berbahan Tepung Mocaf dan 
Tepung Beras Pecah Kulit dengan Tambahan Sari Kurma. Esa Unggul University.

Amri, Mutiara Nisa'.Susilo, Bambang dan Hendrawan Yusuf. 2015. Pengaruh Pengendalian Suhu Berbasis Logika Fuzzy dan Kecepatan Pengadukan pada Evaporator Vakum Double Jacket Terhadap Karakteristik Fisik Permen Susu. Jurnal Bioproses Komoditas Tropis, Vol 3 (2).

Andasuryani,Fadli Irsyad, Hafna Mulyana Pardede. 2017. Pemodelan Kinetik Kehilangan Vitamin C pada Tepung Bayam Merah Pada Beberapa Kondisi Penyimpanan. Prosiding Seminar Nasional FKPT-TPI 2017. Kendari, Sulawesi Tenggara, 20-21 September 2017

Anggraeni, A.C. 2012. Asuhan Gizi Nutritional Care Proces. Yogyakarta : Graha Ilmu.

AOAC (Association of Official Agricultural Chemist). 2002. Official Methods of analysis. AOAC, Washington, DC.

Apriani, Rd Rina Nur. Arpah, M dan Setyadjit. 2011. Formulasi Tepung Komposit Campuran Tepung Talas, Kacang Hijau dan Pisang dalam Pembuatan Brownies Panggang. Jurnal Ilmiah dan Penelitian, Vol 12 (2).

Apriyantono, A., D. Fardiaz, N. L. Puspitasari, Sedarnawati, dan S. Budiyanto. 1989. Petunjuk Laboratorium Analisis Pangan. Pusat Antar Universitas Pangan dan Gizi Institut Pertanian Bogor, Bogor.

Argana Guntur, Kusharisupeni, Diah M. Utari. 2004. Vitamin C sebagai Faktor Dominan untuk Kadar Hemoglobin pada Wanita Usia 20-35 Tahun. Jurnal Kedokteran Trisakti, Vol. 23 (1).

Astawan, M. 2004. Kandungan Gizi Aneka Bahan Makanan. Jakarta : Senior.

Badan Standardisasi Nasional (BSN). 1992. Biskuit. SNI 01-2973-1992.

Barreira, João C.M., M. Antónia Nunes, Beatriz Vieira da Silva, Filipa B. Pimentel,Anabela S.G. Costa, M. Alvarez-Ortí, J.E. Pardo, M. Beatriz P.P. Oliveira. 2019. Almond cold-pressed oil byproduct as ingredient for cookies withpotential health benefits: Chemical and sensory evaluation. Food Science and Human Wellness 8 (2019) 292-298

Barrett, Diane M. Elisabeth, Gracia and Jo Ellen Wayne. 1998. Textural Modification of Processing Tomatoes. Critical Reviews in Food Science and Nutrition, Vol 38 (3) : 173-258.

Basito, Edhi Nurhartadi, Amalia Hari Kusuma. 2013. Pengaruh Penggunaan Tepung Koro Pedang (Canavalia Ensiformis (L) Dc.) Dan Tepung Jagung (Zea Mays L.) Sebagai Substitusi Tepung Terigu Terhadap Karakteristik Fisika, Kimia Dan Sensori Pada Pembuatan Cookies. Jurnal Teknosains Pangan Vol 2 (4).

Baumgartner, B., B. Ozkaya, I. Saka, H. Ozkaya. 2018. Functional and physical properties of cookies enriched with dephytinized oat bran. Journal of Cereal Science 80 (2018) 24-30

Bourne, Malcolm C. 2002. Food Texture and Viscosity : Concept and Measurement $2^{\text {nd }}$ Edition. Elsevier Science \& Technology Books.

Canene-Adams K., et al. 2004. The Growth of The Dunning R-3327-H Transplantable Prostate Adenocarcinoma In Rats Fed Diets Containing Tomato, Broccoli, Lycopene, or Receiving Finasteride Treatment. FASSEB J. 18:A886 (591.4).

DeGarmo, E. P., W. G Sullivan and J. R. Canada. 1984. Engineering Economy. Macmillan Publishing Company. New York.

Ernawati. 2009. Pengembangan Produk Tahu Menjadi Tofu Chips (Kajian Jenis Bahan Baku, Suhu Penggorengan dan Biaya Produksi). Fakultas Teknologi Pertanian. Universitas Brawijaya Malang.

Fatkurahman, R., Atmaka, W., dan Basito. 2012. Karakteristik Sensoris dan Sifat Fisikokimia Cookies dengan Subtitusi Bekatul Beras Hitam (Oryza sativa L.) dan Tepung Jagung (Zea mays L.). Jurnal Teknosains Pangan 1(1)

Firmanto, B. H. 2011. Sukses Bertanam Padi Secara Organik. Bandung : Angkasa

Hadisoeganda, A. W. 1996. Bayam : Sayuran Penyangga Petani Indonesia. Balai Penelitian Tanaman Sayuran. Bandung.

Hendrasty, H. K. 2013. Bahan Produk dan Bakery. Yogyakarta : Graha Ilmu.

Hidayah,Wiwit dan Anasari, Tri. 2012. Hubungan Kepatuhan Ibu Hamil Mengkonsumsi Tablet Fe dengan Kejadian Anemia di Desa Pageraji Kecamatan Cilongok Kabupaten Banyumas. Jurnal Ilmiah Kebidanan, Vol 3 (2).

Hubbard, J. K., Hall, H. H., dan Earle, F. R. Composition of the Component Parts of Sorghum Kernel. Cereal Chemistry. 2009; 27(5): 415-420.

Infante, Rufino Antônio., Dorina Isabel Gomes Nata, Maria Eliza de Castro Moreira, Maria Inês Dantas Bastian, Camila Gonçalves Oliveira Chagas, Marília Regini Nutti, Valéria Aparecida Vieira Queiróz, Hércia Stampini Duarte Martino. 2017. Enriched sorghum cookies with biofortified sweet potato carotenoids have good acceptance and high iron bioavailability. Journal of Functional Foods 38 (2017) 89-99.

Iswari, K. 2015. Pemanfaatan Tomat dan Sirsak sebagai Bahan Dasar Pembuatan Produk Suplemen Kesehatan. J. Hort, Vol 25 (3) : 367376.

Jourkesh M, Sadri I, Sahranavand A, Ojagil A, Dehyanpoori M. 2011. The Effects of Two Different Doses of Antioxidant Vitamin $C$ Supplementation on Bioenergetics Index in Male College Student. Journal of American Science (06) : 852-858. 
Kaur, Maninder., Varinder Singh. 2017. Rajwinder Kaur Effect of partial replacement of wheat flour with varying levels of flaxseed flour on physicochemical, antioxidant and sensory characteristics of cookies. Bioactive Carbohydrates and Dietary Fibre 9 (2017) 1420.

Kaur, Parvinder., Poorva Sharma, Vikas Kumar, Anil Panghal, Jasleen Kaur, Yogesh Gat. 2019. Effect of addition of flaxseed flour on phytochemical, physicochemical, nutritional, and textural properties of cookies. Journal of the Saudi Society of Agricultural Sciences 18 (2019) 372-377

Kundaryanti, Rini., Natasya Fardillah M, Retno Widowati. 2018. Pengaruh Pemberian Jus Bayam Hijau Terhadap Peningkatan Kadar Hemoglobin Pada Ibu Hamil Anemia Di Wilayah Kerja Puskesmas Pasar Minggu Jakarta Selatan Jurnal ilmu keperawatan dan kebidanan nasional 2019; 1 (1).

Kesuma, C.P., Adi.A.C., Muniroh L, 2015. Pengaruh Substitusi Rumput Laut (Eucheuma Cottonii) Dan Jamur Tiram(Pleurotus Ostreatus) Terhadap Daya Terima Dan Kandungan Serat Pada Biskuit. Media Gizi Indonesia,Vol. 10, No. 2: 146-15.

Kim, Hyun Woo., Il Joo Lee, Sea Mi Park, Jang Ho Lee, Minh-Hiep Nguyen, Hyun Jin Park. 2019. Effect of hydrocolloid addition on dimensional stability in post-processing of $3 D$ printable cookie dough. LWT - Food Science and Technology 101 (2019) 69-75

Kusharto, Clara M. 2006. Serat Makanan dan Peranannya Bagi Kesehatan. Jurnal Gizi dan Pangan 1 (2) : 45-54.

Kusuma, Rizal Darma., Basito, Windi Atmaka. 2013. Kajian Karakteristik Organoleptik Dan Fisikokimia Cookies Kombinasi Tepung Terigu Tepung Millet Merah Dan Tepung Ubi Jalar Ungu. Jurnal Teknosains Pangan Vol 2 (4)

Kuswardhani, Diah Sukma dkk. 2003. Fortifikasi Fe Organik dari Bayam (Amaranthus tricolor L) dalam Pembuatan Cookies untuk Wanita Menstruasi. PKMI Institur Pertanian Bogor.

Luthfi, Muhammad., Yanti Meldasari Lubis, Yuliani Aisyah. 2017. Kajian Pembuatan Cookies dengan Penambahan Bubur Bayam Merah (Amaranthus Gangeticus) dan Margarin sebagai Sumber Antioksidan. Jurnal Ilmiah Mahasiswa Pertanian Unsyiah. Volume 2 (4)

Martunis. 2012. Pengaruh Suhu dan Lama Pengeringan Terhadap Kuantitas dan Kualitas Pati Kentang Varietas Granola. Jurnal Teknologi dan Industri Pertanian Indonesi, Vol 4 (3).

Maulida, Dewi dan Zulkarnaen, Naufal. 2010. Ekstraksi Antioksidan (Likopen) dari Buah Tomat dengan Menggunakan Solven Campuran, n-Heksana, Aseton dan Etanol. Skripsi. Jurusan
Teknik Kimia Fakultas Teknik. Universitas Diponegoro. Semarang.

Millah, Irma Ika Izzatul. Wignyanto dan Dewi, Ika Atsari. 2013. Pembuatan Cookies (Kue Kering) dengan Kajian Penambahan Apel Manalagi (Mallus Sylvestrus Mill) Subgrade dan Margarin. Fakultas Teknologi Pertanian, Universitas Brawijaya. Malang.

Molinari, Romina., Lara Costantini, Anna Maria Timperio, Veronica Lelli, Francesco Bonafaccia, Giovanni Bonafaccia, Nicol_o Merendino. 2018. Tartary buckwheat malt as ingredient of glutenfree cookies. Journal of Cereal Science 80 (2018) 37-43

Mudgil, Deepak., Sheweta Barak, B.S. Khatkar. 2017. Cookie texture, spread ratio and sensory acceptability of cookies as a function of soluble dietary fiber, baking time and different water levels. LWT - Food Science and Technology 80 (2017) 537-542

Mulyadi, F.A., S. Wijana, A.I. Dewi, dan I.W. Putri. 2014. Karakteristik Organoleptik Produk Mie Kering Ubi Jalar Kuning (Ipomoea batatas) (Kajian Penambahan Telur dan CMC). Jurnal Teknologi Pertanian 15 (1) : 25 - 36.

Oztürk, Serpil., Inci Cerit, Selime Mutlu, Omca Demirkol, 2017. Enrichment of cookies with glutathione by inactive yeast cells (Saccharomyces cerevisiae): Physicochemical and functional properties. Journal of Cereal Science 78 (2017) 19-24

Paranthaman R, Praveen kumar P, \& Kumaravel S. 2012. GC-MS Analysis of Phytochemicals and Simultaneous Determination of Flavonoids in Amaranthus caudatus (Sirukeerai) by RP-HPLC. Analytical \& Bioanalytical Techniques. 3:5.

Passi, Santosh Jain and Sheila C, Vir. 2001. Functional Consequences of Nutritional Anemia in School Age Children. Nutritional Anemias, CRC Press, Washington, D. C.

Pereira, Daniela. Correia, Paula M. R and Guine, Raquel P. F. 2013. Analysis of the PhysicalChemical and Sensorial Properties of Maria Type Cookies. Acta Chimica Slovaca, Vol 6 (2) : 269-280.

Pestoric, Mladenka., Marijana Sakac, Lato Pezo, Dubravka Skrobot, Natasa Nedeljkovic, Pavle Jovanov, Olivera Simurina, Anamarija Mandic. 2017. Physicochemical characteristics as the markers in predicting the selflife of gluten-free cookies. Journal of Cereal Science 77 (2017) 172-179

Pradipta, Ida Bagus Yoga Vidya Pradipta dan Putri, Widya Dwi Rukmi. 2015. Pengaruh Proporsi Tepung Terigu dan Tepung Kacang Hijau Serta Substitusi dengan Tepung Bekatul dalam Biskuit. Jurnal Pangan dan Agroindustri, Vol 3 (3) : 793-802.

Putri, Mardiana Prasetya dan Setiawati, Yunita Herwidiana. 2015. Analisis Kadar Vitamin C 
pada Buah Nanas Segar (Ananas comosus (L) Merr) dan Buah Nanas Kaleng dengan Metode Spektrofotometri UV-Vis. Jurnal Wiyata, Vol 2 (1).

Ramakrishnan, Usha. 2001. Nutritional Anemias. CRC Press. Washington, D. C.

Rehen, Zasendy., Ivakdalam, Lydia Maria. 2019. Pengaruh Substitusi Rumput Laut terhadap kandungan serat Cookies Sagu (Effect of Seaweed Substitution on Fiber Content of Sago Cookies). Jurnal Agribisnis Perikanan. Vol. 12 No. 1: 157-161

Rohimah I, Sudaryati E, Nasution E. 2013. Analisis Energi dan Protein serta Uji Daya Terima Biskuit Tepung Labu Kuning dan Ikan Lele. J Gizi, Kesehat reproduksi dan Epidemiol 2(6):1-9.

Romalasari, Atika. 2011. Pengaruh Perlakuan Pengemasan dan Suhu Simpan Berbeda Terhadap Kualitas Buah Tomat (Lycipersicon esculentum Mill). Skripsi. Fakultas Pertanian. Institut Pertanian Bogor.

Saati, Elfi Anis. 2014. Eksplorasi Pigmen Antosianin Bahan Hayati Lokal Pengganti Rodhamin B Dan Uji Efektivitasnya Pada Beberapa Produk Industri/Pangan. Jurnal Gamma. Vol 9 (2).

Sainju, Upendra. M, Dris. Ramdane and Singh, Bharat. 2003. Mineral Nutrition of Tomato. Agricultural Research Station, Fort Valley State University. Fort Valley, USA.

Saltveit, M. E. 2005. Fruit Ripening and Fruit Quality. In Heuvenlik Ep (Ed). Tomatoes. CABI Publishing. Wageningen University.

Sanchez-Riveraa, Mirna M., Luis A. Bello-Péreza, Juscelino Tovarb, Mario M. Martinezc, Edith Agama-Acevedoa. 2019. Esterified plantain flour for the production of cookies rich in indigestible Carbohydrates. Food Chemistry 292 (2019) 1-5

Saputra, Hasyim Prayogi., Basito, Edhi Nurhartadi. 2014. Pengaruh Penggunaan Tepung Koro Benguk (Mucuna Pruriens) Dan Tepung Mocaf (Modified Cassava Flour) Sebagai Substitusi Tepung Terigu Terhadap Karakteristik Fisik, Kimia, Dan Sensori Cookies. Jurnal Teknosains Pangan Vol 3 (1)

Setiyowati W., Nisa F. 2014. Formulasi Biskuit Tingggi Serat (Kajian Proporsi Bekatul Jagung: Tepung Terigu dan Penambahan Baking Powder). J Pangan dan Agroindustri 2:224-31.

Seyhun, Nadide. Sumnu, Gulum and Sahin, Serpil. 2003. Effects of Different Emulsifier Types, Fat Contents, and Gum Types on Retardation of Staling of Microwave-baked Cakes. Nahrung Food, Vol 47 (4) : 248.

Shi, John and Maguer, Marc Le. 2000. Lycopene in Tomatoes : Chemical and Physical Properties Affected bby Food Processing. Critical Reviews in Food Science and Nutrition, Vol 40 (1) : 1 42.

Suarez, Hernandez M., Rodriguez, Rodriguez E. M., dan Romero, C. Diaz. 2008. Chemical Compositioan of Tomato (Lycopersicum esculentum) From Tenerife, the Canary Island. Journal Food Chemistry 106 : 1046-1056

Suarni. 2009. Prospek Pemanfaatan Tepung Jagung untuk Kue Kering (Cookies). Jurnal Litbang pertanian 28 (2) .

Subandoro, Rendra Hardian., Basito, Windi Atmaka. 2013. Pemanfaatan Tepung Millet Kuning Dan Tepung Ubi Jalar Kuning Sebagai Subtitusi Tepung Terigu Dalam Pembuatan Cookies Terhadap Karakteristik Organoleptik Dan Fisikokimia. Jurnal Teknosains Pangan Vol 2 (4)

Sudarmadji, Slamet., dkk. 2010. Analisa Bahan Makanan dan Pertanian. Yogyakarta : Liberty Yogyakarta.

Suparmi, Sahri. A. 2009. Mengenal Potensi Rumput Laut: Kajian Pemanfaatan Sumber Daya Rumput Laut Dari Aspek Industri Dan Kesehatan. Jurnal Sultan Agung Vol XII No. 118.

Tensiska. 2008. Serat Makanan. Jurnal Teknologi Industri Pangan. Universitas Padjajaran, Vol 2 : 3-10.

Wahyuni, R. 2010. Pemanfaatan Kulit Buah Naga Super Merah (Hylocereus Costaricensis) sebagai Sumber Antioksidan dan Pewarna Alami pada Pembuatan Jelly. Jurnal Teknologi Pangan (2): 68-85

Winarno, F. G. 2002. Kimia Pangan dan Gizi. Jakarta : PT. Gramedia Pustaka.

Wirakartakusumah, M. A. 1984. Kinetics of Starch Gelatinization and Water Absorption in Rice. PhD Disertation. University of Wisconsin, Madison.

Witono, Judy Retti. Kumalaputri, Angela Justina dan Lukma, Heidylia Stella. 2012. Optimasi Rasio Tepung Terigu, Tepung Pisang, dan Tepung Ubi Jalar, Serta Konsentrasi Zat Aditif pada Pembuatan Mie. Lembaga Penelitian dan Pengabdian Kepada Masyarakat. Universitas Katolik Parahayangan.

Yadav, Shashi Kala dan Sehgal, Salil. 1995. Effect of Home Processing on Ascorbic Acid and $\beta$ carotene Content of Spinach (Spinacia oleracia) dan Amaranth (Amaranthus tricolor) Leaves. Plant Foods for Human Nutrition 47 (2) : 125131.

Yang, Bin., Mengmeng Guo, Zhengtao Zhao. 2020. Incorporation of wheat malt into a cookie recipe and its effect on the physicochemical properties of the corresponding dough and cookies. LWT Food Science and Technology 117 (2020) 108651 
Yudhistira, B, D R Affandi, P N Nusantari. 2017. Effect of green spinach (Amaranthus tricolor L.) and tomato (Solanum lycopersicum) addition in physical, chemical, and sensory properties of marshmallow as an alternative prevention of iron deficiency anemia. IOP Conf. Series: Earth and Environmental Science 102. 